\title{
REVIEWS
}

\section{Review of the Centennial Congress of the International Society for the History of Medicine in Riga}

\section{Prehistory}

The International Society for the History of Medicine (ISHM) is a non-profit international society with the aim to assist and support the historical study of all questions relating to the medical and allied sciences. The Society stimulates and oversees the organization of periodic international congresses in the history of medicine. (ISHM Statutes, 2007)

In 2016, during the 45th ISHM Congress in Buenos Aires, Riga was nominated as a possible venue for the 47th ISHM Congress in 2020. Soon after the nomination, the Latvian Association of the Historians of Medicine started negotiations with possible hosts, supporters and sponsors, including the Riga Stradiñ š University (RSU), Pauls Stradiñ š Museum of the History of Medicine in Riga, ${ }^{1}$ Ministry of Health of the Republic of Latvia, the WHO Country Office Latvia and others. During the ISHM Executive Committee meeting in Beijing in 2017, Riga was confirmed as the venue for the 47th Congress of the ISHM, and Professor Juris Salaks was confirmed as president of the Congress (Fig. 1). In September 2018, during the 46th Congress of the ISHM in Lisbon, Rector of the Rīga Stradinš University Professor Aigars Pètersons invited all members of the ISHM to attend the 47th Congress of the ISHM in Riga in 2020 and launched the congress website: www.ishm2020.com. The Riga Congress was seen as an inauguration event of the celebration of the centenary since the creation of the ISHM in 1921 in Paris (Garnizone \& Salaks, 2020).

1 In the mid-1950s, Pauls Stradinš became a member of the ISHM and intended to invite medical historians from around the world to the opening of the museum of the history of medicine in Riga. His death in August 1958 did not allow the implementation of these plans. 


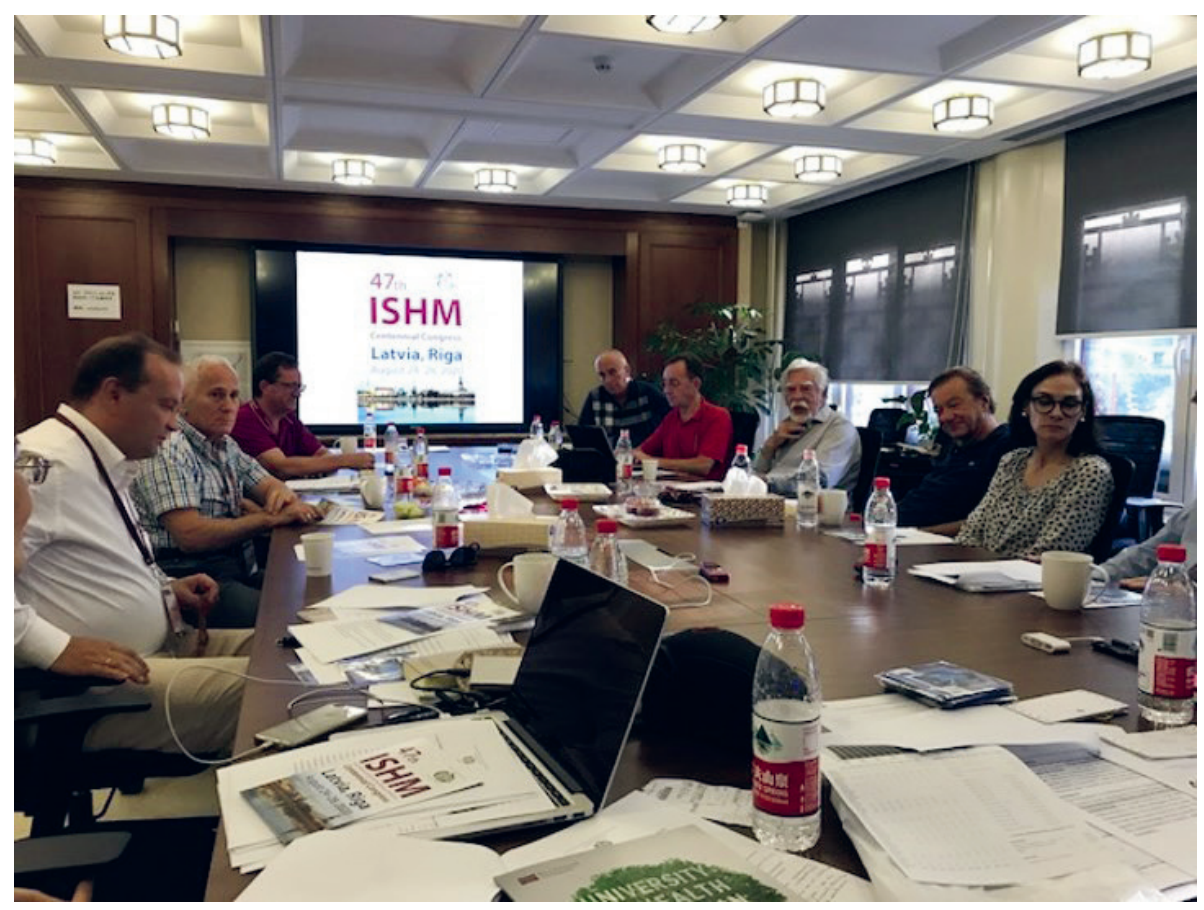

Figure 1. The Executive Committee of the ISHM approved Riga as the venue for the 47th ISHM Congress. Beijing, September 2017. Photo by Aldis Ërglis.

\section{Opening of the 47th Congress of ISHM}

In September 2018, sophisticated preparation work was already carried out, which allowed the congress website to be used as an organizing and communication platform two years before the event. In fact, this meant that it was already possible to register for participation in the congress and send abstracts for possible inclusion in the congress programme. Among the 20 scientific topics of the congress, some unique ones appeared such as ISHM. Towards 100; Medicine around the Baltic Sea Region; History of Medicine: Beyond the Borders and Behind the Curtains; Medical Collections and Collectors; Physicians Outside the Medicine; New Research Technologies in the History of Medicine; Architecture in Medicine; and Environmental Disasters in the History of Medicine.

In early March 2020, the organizers got together with the host, supporters, and sponsors of the congress to share the current status, six months before the 


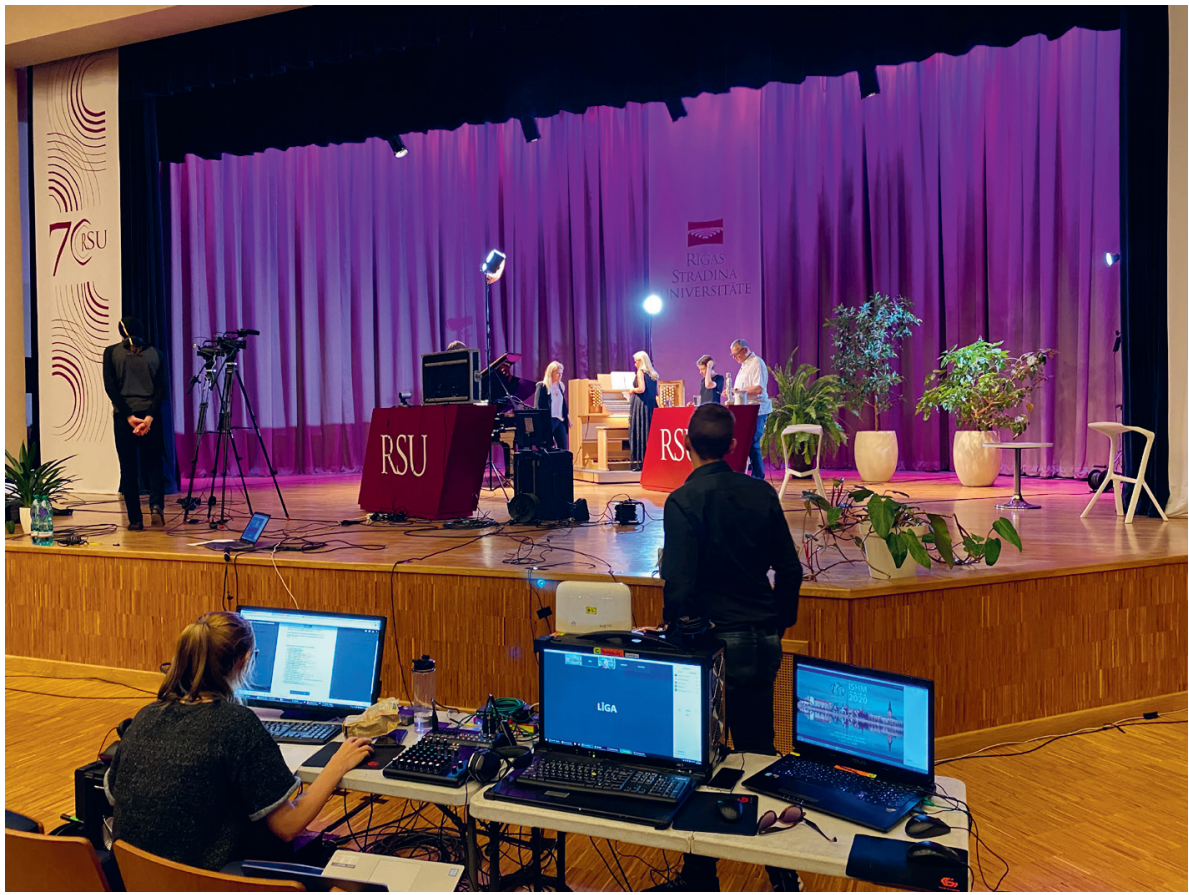

Figure 2. Preparation for the virtual opening of the 47th ISHM Congress in Aula Magna of the Rīga Stradinš University. 24 August 2020. Photo by Edijs Šauers.

event: outcome of the submitted abstracts, a preliminary scientific and social program, and a pre-congress communication plan for delegates and media. At that moment, no one could have imagined how much more different the outcome would be. Two months later, the organizers had to announce a change of plans. After carefully evaluating the global development of the SARS-CoV-2 pandemic, they approached the ISHM Executive Bureau with the proposal to change the dates for the 47th ISHM Congress in Riga to 23-27 August 2021 and got approval. The health and safety of delegates, speakers, and sponsors was the most important priority; the date for the Virtual Opening Ceremony of the 47 th Congress of the ISHM remained as it was initially established, 24 August 2020.

An improvised studio was created on the stage of Aula Magna of the Riga Stradinšs University (Fig. 2). The virtual opening ceremony was led by the president of the congress, Professor Juris Salaks, and congress general secretary Assist. Professor Ieva Libiete and was broadcast on the congress website and Facebook channel. In 
special video speeches, the congress was greeted by RSU Rector Professor Aigars Pētersons, cardiac surgeon, grandson of Professor Pauls Stradinšs, RSU Professor Pēteris Stradiņš and Director of the Pauls Stradiňš Museum of the History of Medicine Kaspars Vanags. Online connections were established with the general secretary of the ISHM Professor Dana Baran from Romania:

We are undoubtedly at a historical crossroads and confronted with new medical challenges that are probably going to change our mentalities and our habits. Possibly in the future, all congresses or meetings should integrate virtual and online communication sessions, because even though online events have many disadvantages, they also have a lot of benefits.

Greetings were also addressed from the president of the satellite symposium 'Anatomy \& Beyond', Pascale Pollier from Belgium.

According to the hundred-year-old protocol of the society's congresses, President of the ISHM Professor Carlos Viesca, in his online connection from Mexico, said:

I am happy to open this congress. It is important to recall that now begins the celebration of the 100 years of the existence of our society. Our society was born in the years immediately after the First World War and in agitated times, rebuilding of the states of Europe, America, international relationships, etc. And with growing consciousness about what signifies history for our identity as humans, our identity as social working people, our identity as medical people, the importance of looking to the future. This question started 100 years ago, and now it is reborn among us. It is important to think of what signifies all this; that we are living for the history of humanity, but also for the history of medicine. The important thing for us, which signifies health, is new discoveries, new problems, new viruses, new illnesses, but also people working for the health of humankind. This centenary opens a hundred more years to the future for us.

And he declared the Congress open. This was followed by online greetings from the national delegates from Poland, Germany, Ukraine, Israel, the USA, Malaysia, Greece, China, Mexico, Brazil, Italy, Argentina, and Canada. The National Delegate of Belgium, grandson of the first President of the Society, Professor Jean Pierre Tricot, emphasized in his speech:

The first ISHM Congress was organized in Antwerp after the First World War. Now we are in a quite different kind of war against the coronavirus, a new microbiological war. Since antiquity, we have been confronted with 
Juris Salaks

Marika Garnizone

different forms of plagues and fevers, and we were always able to eliminate them. (ISHM, 2020)

The 47th Congress virtual opening event was celebrated with a live brilliant performance by Agnese Eglina (piano) and Liene Andreta Kalnciema (organ).

Participants from all over the world-Latvia, Brazil, Italy, the USA, Mexico, Venezuela, Israel, Spain, Portugal, the Russian Federation, Belgium, Germany, Poland, Switzerland, Turkey, Malaysia, Canada, Greece, Singapore, Lithuania, Estonia, Sweden, Finland, and Argentina — watched the live stream of the event. Later a review was published by one of the online participants (Kolotilova, 2020)

\section{First online lectures}

There were 365 days between the opening ceremony of the congress in 2020 and the continuation of the congress on 23 August 2021. Therefore, for the first time, the organizers had a challenging task of maintaining the interest of the participants in the congress and ensuring the continuation of knowledge in the field of the history of medicine.

October started with online lectures and meeting the speakers-viewing the lectures and a discussion afterwards. In a workshop held in Riga, two lectures on politicized medicine related to venerology wards were recorded. Lectures were provided in cooperation with the Baltic-German University Liaison Office.

The first speaker was Professor Florian Steger from the University of Ulm in Germany. His main research fields include questions of history, philosophy, and ethics of medicine: research ethics, clinical ethics, good scientific practice, and issues of injustice in politicized medicine. His lecture was about politicized medicine: 'Closed venerology wards in the German Democratic Republic'.

Another speaker on the topic of politicized medicine in Eastern European dictatorships was Dr. Marcin Orzechowski, also from the Ulm University Institute of the History, Theory and Ethics of Medicine. His lecture was on politicized medicine in the Polish People's Republic, focusing on policy approaches towards combatting venereal diseases in 1945-1989.

Later, the speakers published articles on the topic politicized medicine in Acta medico-historica Rigensia for 2020 (Orzechowski, Schochow \& Steger, 2020) as 


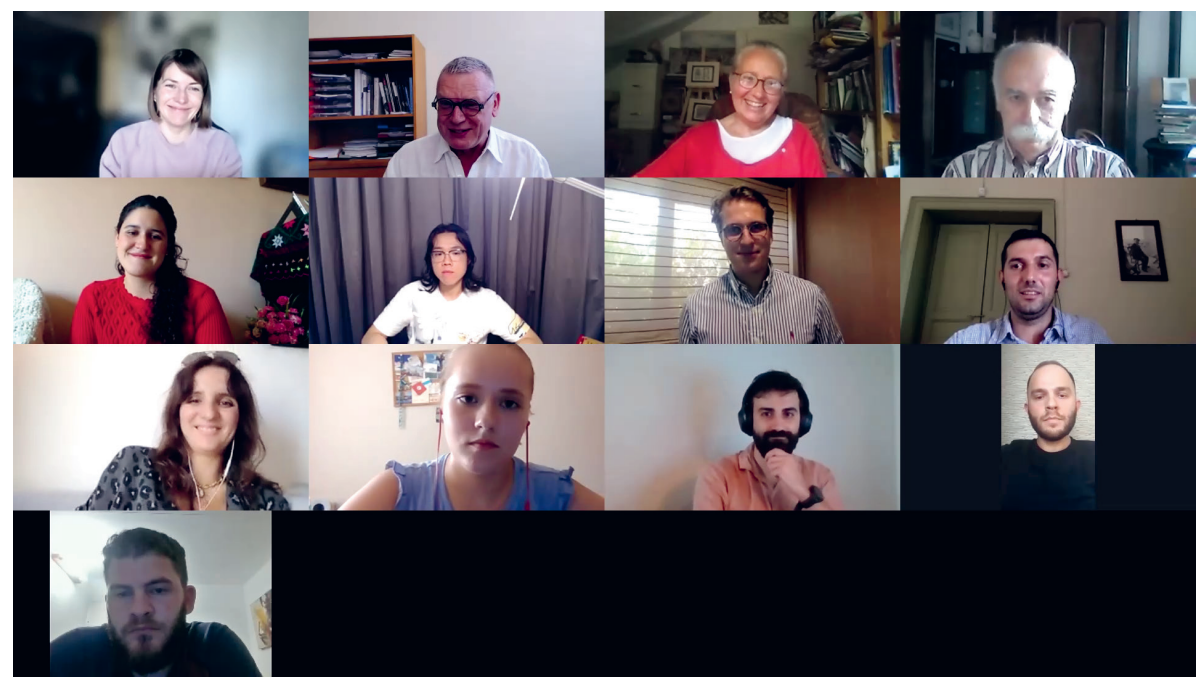

Figure 3. The closing Zoom session of the First Summer School on the History of Medicine. Photo by Aldis Ërglis.

well as comments on the articles to expand joint interdisciplinary research on this topic in three universities in Latvia, Lithuania and Estonia (Salaks, Žalnora \& Toomsalu, 2020).

Online lectures in the format 'Member to Members' were also held by Professor Tatiana Sorokina from People's Friendship University of Moscow, Russia; Professor Emeritus Avi Ori from Tel Aviv University and Professor Yoel Donchin from Hebrew University of Jerusalem, Israel; Associate Professor Maria Sergeeva and Associate Professor Evgeniya Panova from Sechenov University, Moscow (ISHM Newsletter, 2021).

\section{The first joint project of ISHM and RSU: Summer school on the history of medicine}

Already in 2017, the offer from the RSU Institute of History of Medicine was approved to conduct the first summer school in the history of medicine for young scholars in cooperation with ISHM a week before the congress. The ISHM, RSU and Hoffmann-La Roche became the sponsors of the first summer school on the history of medicine. Only nine participants were selected from amongst the 


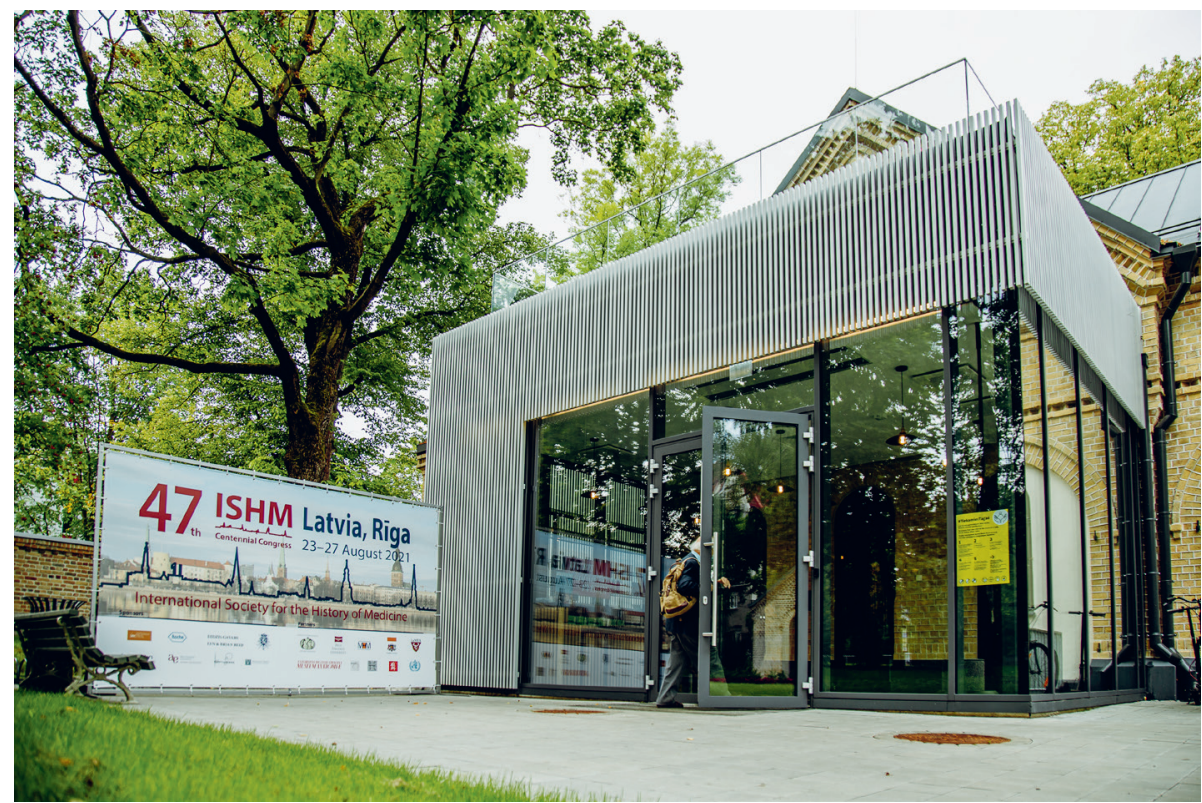

Figure 4. RSU Anatomy Museum—the venue of the 47th ISHM Congress. Copyright holder RSU.

applicants. Due to the pandemic, the summer course was moved online and took place once a week on a Zoom platform from 1 July to 12 August 2021. The summer course was held by Professor Emerita and Hannah Chair of the History of Medicine Jacalyn Duffin of Queen's University in Kingston, Canada (ISHM, 2021). The invited guest lecturer at the summer school offered more than twenty topics of her scientific research for selection by the school participants. Students voted and chose the following five topics:

- First, Do No Harm: History of treatment, pharmacology, and pharmaceuticals

- Plagues and Peoples: Epidemic diseases in history

- Medical Miracles: Doctors, saints, and healing through the Vatican Archives.

- Palliative Care: The oldest profession?

- Poisoning the Spindle: The discovery of the vinca alkaloids

Participants were from Portugal, Italy, Russia, Latvia, Mexico, Germany, Israel, Lithuania and China (Fig. 3). All of them were granted a certificate to participate in the 47th ISHM Congress scientific events (23-27 August 2021) without a fee, online or onsite. Two of the summer school students were invited to be moderators of the poster sessions at the congress and successfully handled the 
role entrusted to them in the congress program. Based on the results of the first school in the history of medicine, it was decided that this project of the ISHM and the RSU will be continued and subsequent schools with the participation of guest lecturers from the society on the eve of each subsequent congress and in the host country of the congress will be organized. The society sees this as an opportunity to attract young researchers to become members of the ISHM.

\section{The hybrid congress of ISHM}

For everyone around the world, this year has been challenging, full of learning to adapt to social distancing and online environments. No matter how much everyone missed meeting people face-to-face, it was clear that the congress cannot take place fully onsite. The university's technical support team and a professional broadcasting company joined the organizers to ensure that the hybrid congress can happen simultaneously onsite and online. The 48 delegates who were able to travel (had a certificate of full course vaccination) came to the congress and visited onsite, while others joined online. All sessions were held at the reconstructed RSU Anatomy Museum in Riga (Fig. 4). During each session, participants were able to present onsite, online, and in a few cases via pre-recorded video presentations, sent in advance. All panels, scientific sessions, and main ceremonial events were broadcast live at the congress website for all delegates, but four plenary lectures were broadcast free for all at the congress website and on two Facebook channels (Fig. 5).

Over the seven days of the centennial 47th ISHM Congress in Riga, 4 plenary sessions, 3 panel discussions, 8 scientific sessions, 2 poster sessions, 2 satellite symposiums 'Bridging the Baltic' and 'Anatomy \& Beyond', as well as an extensive social programme were held. It was a very intense week for the delegates who were able to attend the congress onsite in Riga and no less busy for the delegates online with 38 hours of broadcasts from various scientific platforms of the congress. 


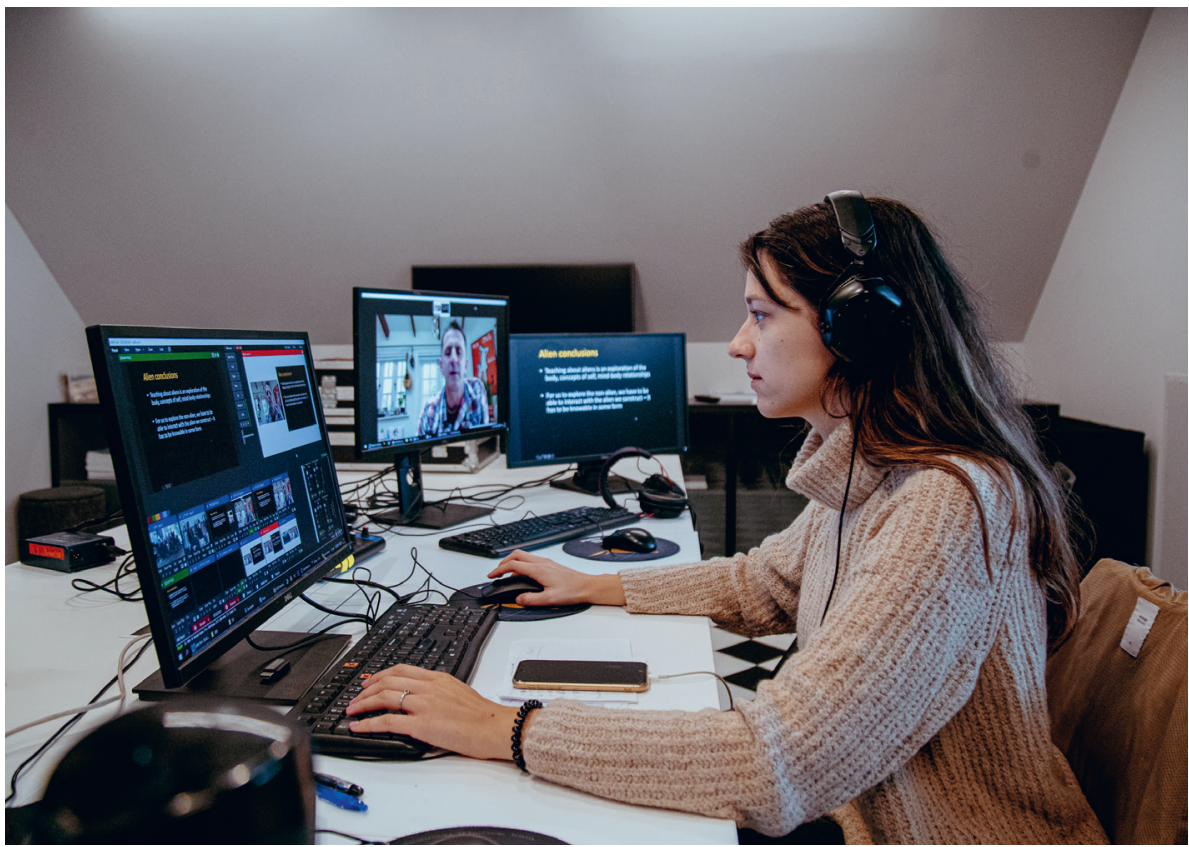

Figure 5. Thirty-eight hours of online broadcast of the ISHM congress in Riga. Copyright holder RSU.

\section{Pre-symposium 'Bridging the Baltic: Medicine in the Baltic Sea Region'}

This satellite symposium was organized by the Heinrich-Heine University Düsseldorf, Rīga Stradinš University, Odense University, and Lund University. The network 'Bridging the Baltic: Medicine in the Baltic Sea Region' brings together researchers who currently work on aspects of medical history in the Baltic Sea region to illuminate currents of ideas and areas of cooperation and conflict. One of the main themes of the network is how the circulation of knowledge in medicine played out during the Cold War. How did science exchange in medical practice across the Iron Curtain? The Riga meeting has also been characterized by interdisciplinarity with speakers from different fields, such as historians, physicians, scholars of other medical studies, health care economists, politicians, and diplomats (Fig. 6). The symposium was supported by the German Research Foundation and the European Association for the History of Medicine and Health (Bridging the Baltic, 2021). 


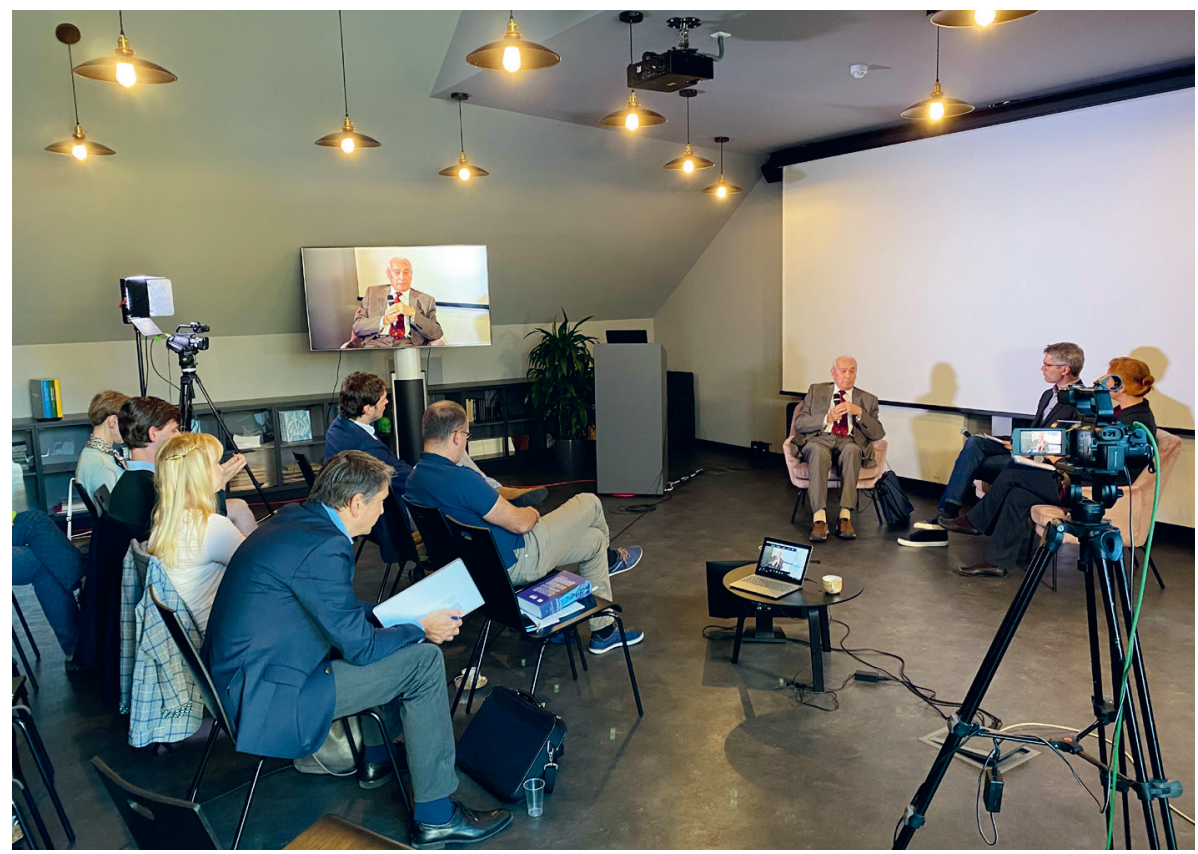

Figure 6. Interview with former Minister of Foreign Affairs of the Republic Latvia, Dr. Georgs Andrejevs. Photo by Juris Salaks.

\section{Satellite symposium 'Anatomy \& Beyond'}

The symposium 'Anatomy \& Beyond' was curated by Pascale Pollier and was a collaborative project of the Association Européenne des Illustrateurs Médicaux et Scientifiques (AEIMS), The Medical Artists' Association of Great Britain (MAA), Biological and Medical Art in Belgium (BIOMAB), Art Researches Science International Collaboration (ARSIC), International Society for the History of Medicine (ISHM) and the RSU Anatomy Museum. The event was supported by the Embassy of Belgium to Sweden and Latvia, the General Representation of the Government of Flanders in Poland and the Baltic States, Vesalius Trust, and the Honorary Consul of Belgium in Latvia, Dr. Didzis Gavars.

The symposium 'Anatomy \& Beyond' explores new ways in envisaging the role of art and anatomy, reimagining humanity on earth and beyond: in the here and now and in possible post-terrestrial futures. Artists, anatomists, scientists, medical doctors, and museum curators are forced to rethink the porous limitations of our organic earthbound bodies and the role to be played by advancements 


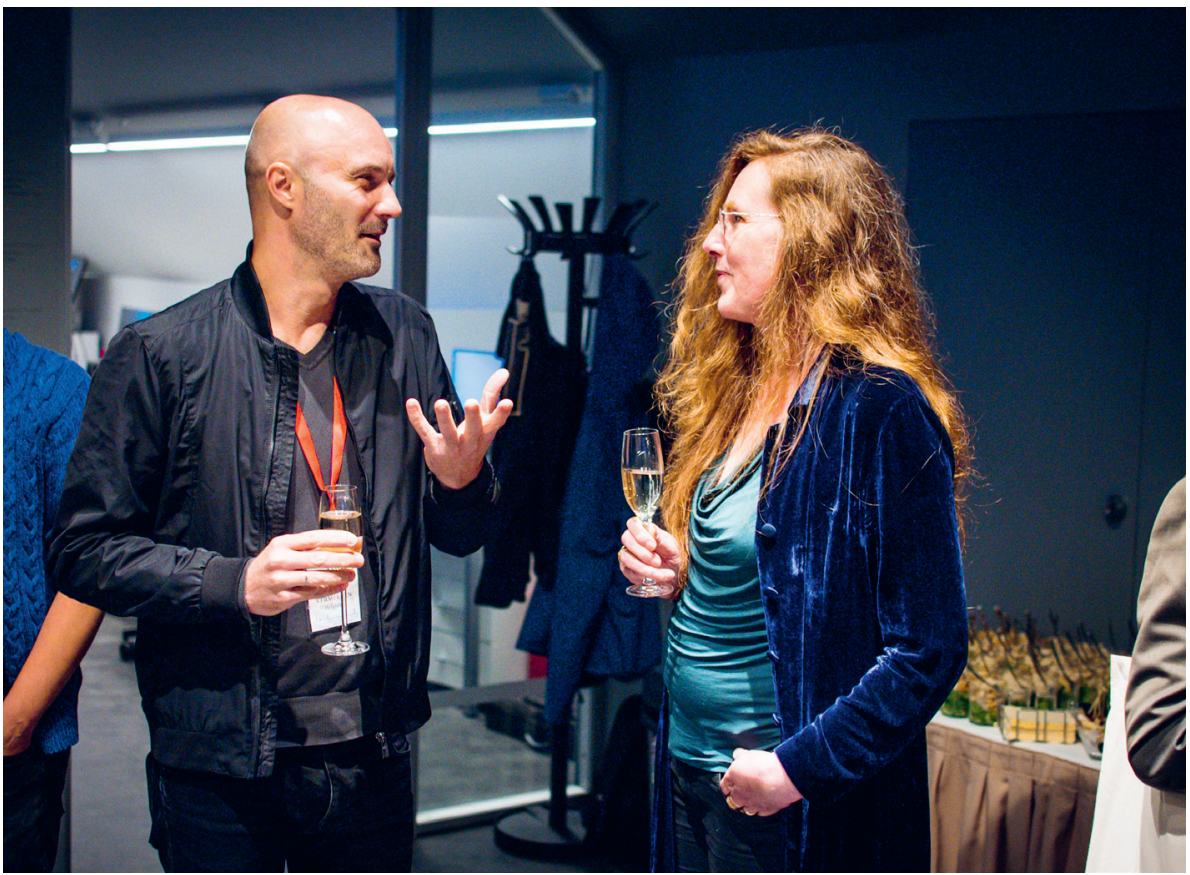

Figure 7. Medical artist Pascale Pollier and invited speaker Angelo Vermeulen at the vernissage of the exhibition of artworks 'Anatomy \& Beyond'. Copyright holder RSU.

and revolutionary technological physical enhancements to our bodies that are occurring with ever gathering speed as we venture into new arenas and space. (Anatomy \& Beyond, 2021)

The one-day symposium was closed with a vernissage of the 'Anatomy \& Beyond' exhibition of artworks by seven artists: Andrew Carnie (UK), Eleonor Crook (UK), Joe Davis (USA), Bryan W. Green (UK), Mara G. Haseltine (USA), Pascale Pollier (UK/BE), and Nina Stellars (AU). It is a sequel to Pascale Pollier's successful and inspirational touring exhibition 'Fabrica Vitae', and the accompanying conference Vesalius Continuum, of which she was the curator and chief organizer. (Fig. 7) 


\section{Keynote speakers}

Long before the opening of the 47 th Congress, an agreement was reached with the invited key speakers for four plenary sessions, and each lecture was announced in advance on the homepage of the congress. Unlike previous congresses, the opportunity to listen to lectures on the spot or online in a webinar mode via the congress and Facebook channels was not only for the congress delegates, but also for everyone who found the announced topics interesting. Therefore, the online audience during live broadcasts ranged from 390 to 630 people.

Professor Emerita Jacalyn Duffin (Canada) is a haematologist and historian who held the Hannah Chair of the History of Medicine at Queen's University from 1988 to 2017. A former president of both the American Association for the History of Medicine and the Canadian Society for the History of Medicine, she is the author or editor of eleven books and many articles and holds several awards for teaching and research, and is a Fellow of both the Royal Society of Canada and the Canadian Academy of Health Sciences. A supporter of the medical humanities, she has been a contributing editor of the online Literature, Arts, and Medicine Database since 1995.

Her research focuses on disease, technology, religion and health policy. She runs an activist website for the current drug shortage problem and a collaborative translation project for the 17th-century Latin author, Paolo Zacchia (Duffin, 2021). Her most recent research was on the history of a medical expedition to Easter Island, led by Canada in 1964-1965, about which she spoke in Riga, entitled Stanley's Dream: The Medical Expedition to Easter Island.

Nils Hansson, PhD (Germany) is an associate professor in the Department for the History, Theory and Ethics of Medicine at the Heinrich Heine University of Düsseldorf. His scholarly interests include the enactment of excellence in medicine, especially the Nobel Prize, the award's gender gap in medicine, knowledge transfer in the Baltic Sea region. He has co-edited the volumes Attributing Excellence in Medicine: The History of the Nobel Prize (2019, Brill) and Explorations in Baltic Medical History, 1850-2015 (2019, Rochester Studies in Medical History). Hansson has organized Nobel Prize symposia at Harvard Medical School, McGill University, Charité University Hospital Berlin and Berne University. He has received several awards for his Nobel Prize research, e.g., the Axel Hirsch Prize in 2017 and the Bengt Lindskog Prize in 2019 (HHU, 
Juris Salaks

Marika Garnizone

2019). His plenary lecture was 'How (not) to win the Nobel Prize: Winners and losers in Nobel Prize history'.

Dan Healey is a professor of modern Russian history at the University of Oxford. He has explored the history of homosexuality in tsarist and Soviet Russia. In his book Russian Homophobia from Stalin to Sochi (2018, Bloomsbury Academic), he looks at the recent politics of homophobia in Russia in a historical perspective.

He has written a monograph on early Soviet forensic medicine, chapters, and articles on forensic psychiatry, and numerous articles on the history of gender and sexuality in modern Russia.

Healey has long had an interest in the Soviet Gulag forced-labour camp system and, in particular, its medical services and their history. His current project explores the organization and practice of medicine in Stalin's forced labour camp system, the Gulag Archipelago. The Soviet camps spanned the length and breadth of the Soviet Union, and the Gulag became a byword for cruelty and human degradation. Yet, archival sources from the camp system itself reveal the operation of an extensive and surprisingly sophisticated medical service. Embedded in the organization of the secret police who ran the camps, the Gulag's medical clinics, stations and hospitals present a puzzle for the historian: why have these places apparent humanity in the midst of suffering and high mortality? In this talk, Healey focused on published and unpublished memoirs of the doctors and nurses, museum collections, and reminiscences of prisonerpatients and prisoner-medics, to illuminate the experience of medical workers in Stalin's penal system (Dan Healey, 2021). The title of his plenary lecture was 'The notebooks of Gulag doctors: Medical service in Stalin's labour camps'.

Alexander Lukas Bieri has been the curator of the Roche Historical Collection and Archive for more than twenty years. He is responsible for the in-house museums, collections, and archives which include major assets on the history of pharmacy, medicine, and art (and an anatomical collection). His publications include works on art and architectural history as well as on the history of science and business. He is currently chairman of the Section on Business Archives of the International Council on Archives and of the Section on Archives of the Chemical and Pharmaceutical Industry of the German Business Archivists Association. Alex is also a member of ICOM Switzerland and, in this capacity, a specialist in twentieth-century interior design. Based on a rare find in one of Roche's collections, he developed an interest in the danse macabre a long time ago. He found out that the art form of the danse macabre offers a fascinating 


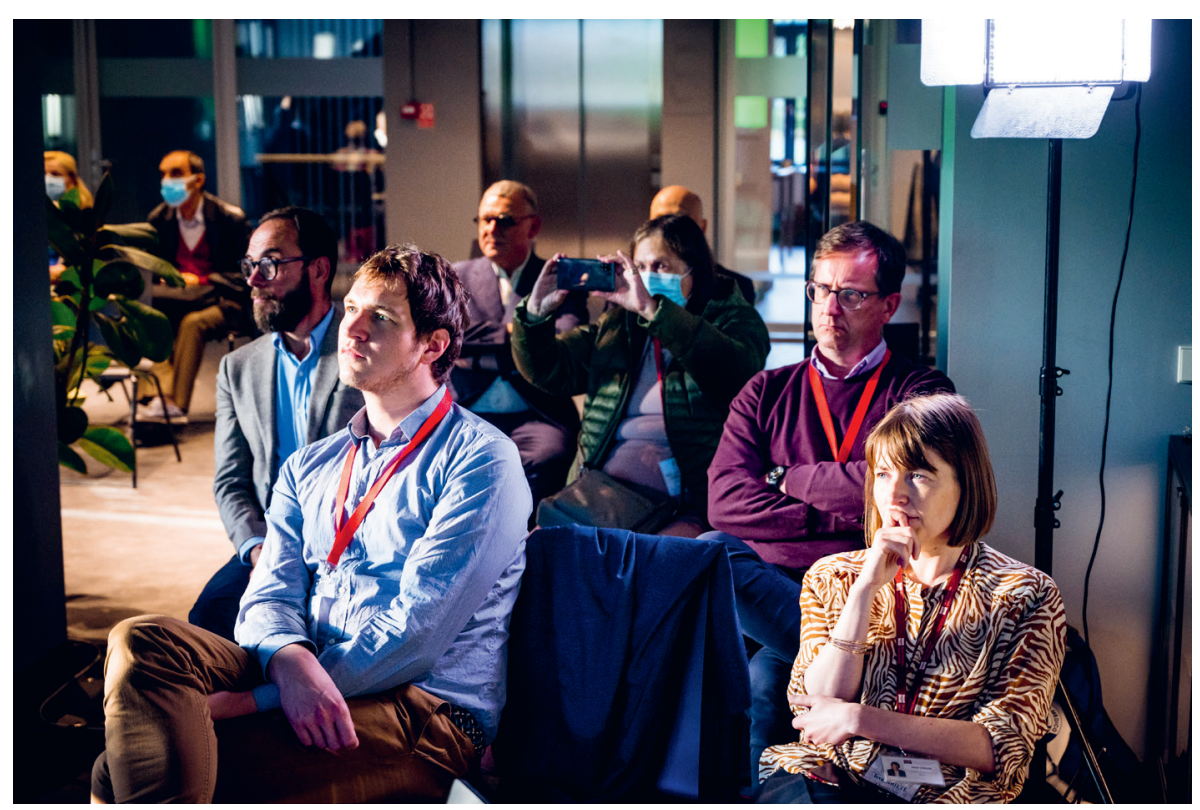

Figure 8. Onsite participants of the panel discussion. Copyright holder RSU.

insight into the artistic development of the depiction of humans. It also allows one to highlight the transformative power that Andreas Vesalius' De Humani Corporis Fabrica had on art in its time and beyond. Furthermore, the history of danse macabre makes changing societal attitudes toward death understandable. (Bieri, 2021) Bieri's lecture, 'Andreas Vesal's lasting impact on the art of Danse Macabre' was a joint plenary session lecture for the 47th ISHM Congress and the satellite symposium 'Anatomy \& Beyond'.

\section{Panel discussions}

The 47th ISHM Congress also offered for all delegates panel discussions with a team of experts and an appointed moderator for each panel session. It was a useful way to trigger an exchange of views among experts and to answer the audience's questions. All panel discussions followed the plenary lectures, which were related to the topic of the key speaker and took place onsite with invited experts onsite and online. The first panel discussion was moderated by Nils Hansson (Heinrich Heine University, Düsseldorf) on the topic 'Gender award gap? (In)visibility of 
Juris Salaks

Marika Garnizone

omen in medical recognition and award culture'. The panelists included Marika Garnizone (Latvia), Jacalyn Duffin (Canada), and Jocalyn Clark (UK). Another panel was held as a joint event with the satellite symposium 'Anatomy \& Beyond' and covered the topic 'Death and beyond'. In the role of the moderator was Alya Dirix (Belgium and Greece), coordinator of the government administration of the city of Brussels. Her experts underlined more specific themes, such as 'Dealing with the dead: Sentiment versus modernity' by anatomist and Gordon museum curator William Edwards (UK), 'Should humans from the past exist as digital humans in the future' by Mark Roughley (UK), and diplomat and writer Theo Dirix (Belgium and Greece) covered the topic 'How would Sophocles's Antigone bury and rebury her brother tomorrow?'. The last panel was in between the Dan Healey planary lecture and the two final breakout sessions, and united by the title 'Medicine and totalitarianism' (Fig. 8). The on-site moderator was Florian Steger from Ulm University (Steger, 2021) with two panelists, Marcin Orzechowski (Germany) and Ineta Lipša (Latvia). The topic attracted attention already during the preparation of the congress and was extensively presented in the fixed speeches of the congress delegates.

\section{Mark Mirsky Prize: A new award for historians of medicine}

In honour of the leading Russian historian of medicine, Prof. Mark Mirsky (1930-2010), his family, in cooperation with ISHM, established a new research award in 2021. The Mark Mirsky Prize will be awarded for the most important scientific works in the field of the history of medicine at each congress of ISHM starting from the 47th ISHM Congress in Riga. The cash prize is 3,000 euros. The laureate will be selected by the scientific board of the congress.

Professor Mark Mirsky was a long-time full member of the International Society for History of Medicine and served as chairman of many scientific sessions of ISHM congresses and meetings. He was a fervent supporter of the humanities and a sharp expert in the history of medicine. The ISHM honours his dedication and thanks his family members who sponsored the Mark Mirsky Prize for the first time this year, by naming the ISHM Award Diploma in his honour. In addition, he was a frequent visitor in Riga and always maintained professional contacts with the members of the Latvian Association of Medical Historians.

The award ceremony took place for the first time during the closing ceremony 


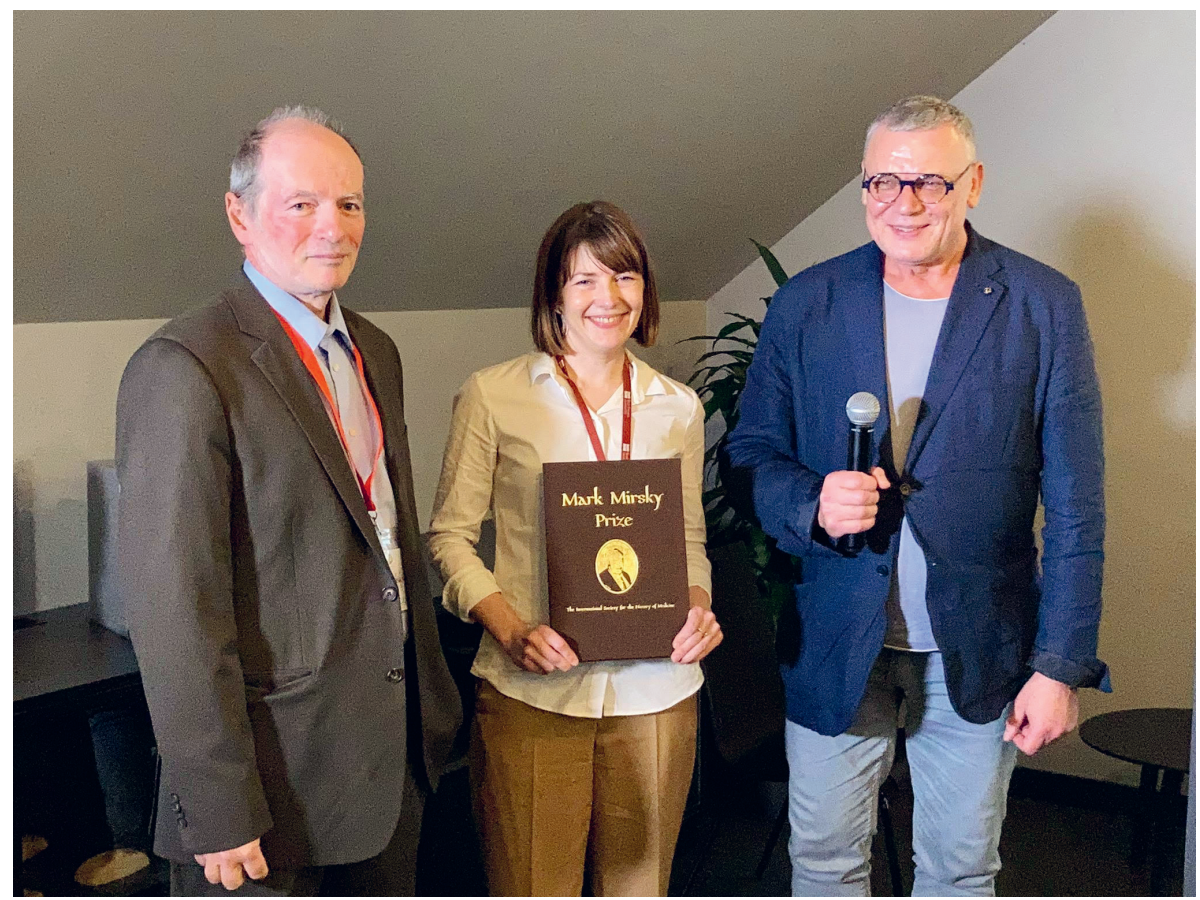

Figure 9. Professor Mark Mirsky Prize, the first award ceremony. From the left: Vladimir Mirsky, leva Lībiete, and Juris Salaks. Photo by Aldis Ërglis.

of the 47th ISHM Congress in Riga. Professor Mark Mirsky's son, professor of the Brandenburg University of Technology, Vladimir Mirsky, and his wife visited Riga to attend the award ceremony. The first ever Mark Mirsky Prize was given to Assistant Professor leva Lïbiete from Rīga Stradinš̌ University for her research presented at the congress, 'A Description of Syndromic Cryptophthalmos by Poet Daniel Hermann in De monstroso Partu..., Published in Riga, 1596'. A diploma and a symbolic check for 3,000 euros were presented to Ms. Ieva Libiete by Professor Vladimir Mirsky (Fig. 9). Later, the laureate of the first Mark Mirsky award sent to the treasurer of the ISHM a request to transfer the entire amount of the prize to the account of the Medical Museum's Endowment Fund in Riga to support young medical history scholars.

In the closing speech, President of the 47th ISHM Congress Professor Juris Salaks said:

I would like to thank all the committees of the congress for their work in preparing the congress in unusual conditions, all the members of the ISHM 
Juris Salaks

Marika Garnizone

who supported the congress by participating onsite in Riga or online, the outstanding key speakers, moderators of panel discussions and sessions chairs, the Rigga Stradinš̌ University for the opportunity to hold our convention in the hospitable premises of the New Museum of Anatomy and technological support, as well as all the partners and sponsors that have made the congress special and worthy of the ISHM century.

The 48th Congress of the ISHM will take place next year in Iaşi, Romania.

\section{Juris Salaks}

Rīga Stradiṇš University, Latvia

\section{Marika Garnizone}

Rigga Stradiņš University, Latvia

\section{References}

Anatomy \& Beyond (2021), 'About'. Retrieved from https://www.anatomy-and-beyond. com/about [accessed 24 Sep 2021]

Bieri, A. L. (2021), 'Andreas Vesal's lasting impact on the art of the danse macabre, 47 th ISHM Congress. Retrieved from https://ishm2020.rsu.lv/alexander-lukas-bieri [accessed 24 Sep 2021]

Bridging the Baltic (2021), 'Symposia,' Bridging the Baltic: Medicine in the Baltic Sea Region. Retrieved from https://balticmedicine.wordpress.com/ [accessed 24 Sep 2021]

Duffin, J. (2021), 'About,' Jacalyn Duffin. Retrieved from https://jacalynduffin.ca/ [accessed 24 Sep 2021]

Garnizone, M. \& Salaks, J. (2020), 'The International Society for the History of Medicine begins the celebration of its 100th anniversary in Latvia,' Acta medicohistorica Rigensia, vol. 13 (32), pp. 93-103. https://doi.org/10.25143/amhr.2020. XIII.06

Healey, D. (2021), 'Meet the speakers,' 47th ISHM Congress. Retrieved from https:// ishm2020.rsu.lv/dan-healey [accessed 24 Sep 2021]

HHU (2019), 'Exzellenzforschung: Bengt-Lindskog-Preis für PD Dr. Nils Hansson,' Heinrich-Heine-Universität Düsseldorf, 3 August. Retrieved from https://www. hhu.de/en/about-hhu/press-and-marketing/current-news/press-releases-hhu/newsdetailansicht/bengt-lindskog-preis-fuer-pd-dr-nils-hansson [accessed 24 Sep 2021] 
ISHM (2020), 'News: Recording of the virtual opening of the 47. Congress of the ISHM (2020),' 47th Congress of ISHM. Retrieved from https://ishm2020.rsu.lv/ news/recording-virtual-opening-47-congress-ishm-available [accessed 24 Sep 2021]

ISHM (2021), 'News: 1st ISHM summer school on the history of medicine,' 47th Congress of ISHM. Retrieved from https://ishm2020.rsu.lv/news/1st-ishm-summerschool-history-medicine [accessed 24 Sep 2021]

ISHM Newsletter (2021), 'Members to Members: ISHM members' lectures online, spring session.' Retrieved from http://www.vesalius.org.uk/images/documents/ newsISHM21-01_Spring_2021.pdf [accessed 24 Sep 2021]

ISHM Statutes (2007), By-laws adopted by the General Assembly, Article 2, The International Society for the History of Medicine. Retrieved from https://www. biusante.parisdescartes.fr/ishm/eng [accessed 24 Sep 2021]

Kolotilova, N. N. (2020), 'Otkrytie 47 Kongresa Mezhdunarodnovo obshchestva ustorikov mediciny' [Opening of the 47th Congress of the International Society of the History of Medicine], Zhizn Zemli, vol. 42, no. 3, pp. 379-380.

Orzechowski, M.; Schochow, M. \& Steger, F. (2020), 'Combatting venereal diseases as an instrument of politicised medicine. An analysis of the example of the Soviet Occupation Zone in Germany, the German Democratic Republic, and the Polish Peoples' Republic,' Acta medico-historica Rigensia, vol. 13(32), pp. 58-82. https://doi.org/10.25143/amhr.2020.XIII.04

Salaks, J.; Žalnora, A. \& Toomsalu, M. (2020), 'Comments on the article 'Combatting venereal diseases as an instrument of politicised medicine. An analysis of the example of the Soviet Occupation Zone in Germany, the German Democratic Republic, and the Polish Peoples' Republic' by Marcin Orzechowski, Maximilian Schochow and Florian Steger,' Acta medico-historica Rigensia, vol. 13(32), pp. 83-92. https://doi.org/10.25143/amhr.2020.XIII.05

Steger, F. (2021), 'Univ.-Prof. Dr. Florian Steger,' Mitarbeiter des Instituts für Geschichte, Theorie und Ethik der Medizin, Universität Ulm. Retrieved from https://www.uniulm.de/med/gte/mitarbeiter/mitarbeiter/steger-florian-univ-prof-dr/ [accessed 24 Sep 2021] 